\title{
室內智慧施工錐
}

\section{Smart Indoor Construction Cone}

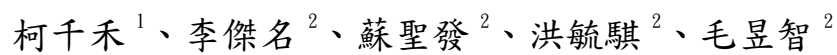 \\ ${ }^{1}$ 教授, 國立屏東科技大學, 土木工程系, Email：ko@mail.npust.edu.tw \\ ${ }^{2}$ 專題生, 國立屏東科技大學, 土木工程系, Email：csjacker08156@gmail.com
}

\section{摘要}

建築施工時, 管理者都會想要知道現場的施工情況, 但管理者不可能常常都在現場 觀看, 例如夜間的時候, 工地現場沒有人在, 外面的人進入工地喝酒、閙事等, 管理人 員無法於第一時間瞭解現場情形, 往往都是到了隔天才知道現場被人闖入。本研究目的 為運用機器人技術開發可自行移動、遠端監控現場、與施工現地互動並能主動警示用路 人之室內智慧施工雃, 達到人不在現場也能知道現場情況, 以降低工地被人闖入之意外, 和減低人力及時間成本, 提升管理績效。首先, 本研究透過統一塑模語言分析與設計智 慧施工錐, 透過需求分析瞭解室內智慧施工錐功能, 並依需求進行設計, 接著, 依據分 析與設計結果, 建構室內智慧施工錐並測試系統功能, 最後, 以實際工地現場驗證室內 智慧施工錐之可行性, 並進行經濟效益評估, 本研究設計之智慧施工錐能達到即時監控 的功能, 並能透過遠端監控功能使管理者隨時了解施工現地情況, 進而提升整體施工效 率。

關鍵詞：建築施工、施工錐、遠端監控、用路警示、機器人

\section{1. 研究動機}

工地管理者對於工地安全及工程進度 的重視, 工地安全像我們經常在社會新聞 上看到, 有人闖入工地在工地裹頭喝酒打 架鬧事。工程進度為管理者監控需求, 工 人在施工現場施工，管理者監控著工人施 工是否確實及進度是否落後。施工三角錐 是工程的必備設備, 將工地隨處可見的三 角錐與監控設備結合在一起可以減少我們 監控設備在於工地的差別性, 將監控設備 有效的與環境結合。現今無線網路的普及 率已成熟。

\section{2. 研究目的}

增進建筑工程上的管理。維護並提高 工地安全。增加工地管理效益。使施工過 程透明化, 提供工地即時影像供管理者即
時管理, 並針對管理者意見改善缺失, 提 升工程品質，落實類似於『即時監控』的 概念。讓管理者能不受距離的限制來藉由 監控系統, 第一時間的瞭解到施工進度與 狀況, 如有發生任何問題就可以即刻的與 工地的現場人員進行溝通並轉回正軌, 以 避免錯誤的繼續加工造成人力、時間與成 本上的浪費。實踐精實營建 [1]精神 (减少 浪費，提升價值）。

\section{3. 研究方法}

我們於市面上寻找眾多機器人, 參考 其運作方式, 並找寻相關資料, 到市面上 購買控制面板, 再經由教授指導, 從構想 到設計到組裝, 組裝過程中了解其優缺點, 爾後提出設計標準、目標與理想。 